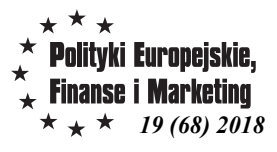

Robert Nowacki

Wyższa SzkołaFinansów i Zarządzania w Warszawie

\title{
Percepcja reklamy artykułów żywnościowych i jej znaczenie w procesach decyzyjnych konsumentów
}

\section{PERCEPTION OF ADVERTISING OF FOOD PRODUCTS AND ITS IMPORTANCE IN CONSUMER DECISION-MAKING PROCESSES}

\begin{abstract}
Celem artykulu jest ocena postrzegania i percepcji reklamy artykułów żywnościowych $w$ spoteczeństwie polskim oraz jej wplywu na decyzje zakupowe konsumentów. Podstawa artykułu sq wyniki badań ankietowych przeprowadzonych w 2014 roku wśród populacji powyżej 15 roku życia. Z badań wynika, że reklamy artykułów żywnościowych dość często oceniane sq jako atrakcyjne $i$ wiarygodne, a podatność na oddzialywanie reklamy artykutów żywnościowych deklaruje niespetna połowa badanych. Występuje przy tym duże zróżnicowanie ocen z punktu widzenia zarówno cech demograficznych respondentów, jak i poszczególnych kategorii produktowych.
\end{abstract}

Slowa kluczowe: reklama, artykuły żywnościowe, atrakcyjność reklamy, wiarygodność reklamy.

Wstęp

Wraz z rozwojem konkurencji i intensyfikacją działań z zakresu komunikacji marketingowej wzrasta zainteresowanie skutecznością podejmowanych przez przedsiębiorstwa procesów promocyjnych. Dotyczy to również reklamy. Jest ona jednym z kluczowych instrumentów marketingowych służących wywieraniu wpływu na zachowania konsumentów. O jej znaczeniu świadczą m.in. rosnące wydatki reklamowe. Według danych firmy Starcom ${ }^{1}$ wartość rynku reklamowego wyniosła w 2016 r. 8331 mln zł i była o 3,0\% wyższa niż rok wcześniej, a w stosunku do roku 2013 wzrost wyniósł aż $17,5 \%$. Znaczącą rolę $w$ wydatkach reklamowych stanowią nakłady ponoszone przez producentów artykułów żywnościowych. Wydatki reklamowe na kategorię żywność wraz z napojami i alkoholami wyniosły w 2016 r. 1317,0 ml zł (co stanowiło 15,8\% ogółu wydatków), dając jej pozycję największego sektora reklamowego. W porównaniu z rokiem poprzednim wydatki te wzrosły o 36,9 $\mathrm{mln}$ zł (czyli o 2,9\%). Motorem tego wzrostu były przede wszystkim napoje i alkohole - wartość ich reklamy zwiększyła się bowiem o 7,2\% przy 1,1\%-owej dynamice żywności.

Na tym tle warto zastanowić się, jaka jest skuteczność działań reklamujących artykuły żywnościowe. Celem opracowania jest ocena postrzegania reklam artykułów żywnościowych w społeczeństwie polskim z punktu widzenia czterech podstawowych wy-

\footnotetext{
${ }^{1} 3$ proc. więcej na reklamy w Polsce, internet zyskuje kosztem prasy i telewizji, mocno w górę branża handlowa (analiza). http://www.wirtualnemedia.pl/artykul/wydatki-reklamowe-w-polsce-2016-internet-zyskujekosztem-prasy-i-telewizji-branza-handlowa [dostęp: 1.07.2017].
} 
miarów - atrakcyjności, wiarygodności, motywowania do zakupu oraz rzeczywistego wpływu na decyzje zakupowe konsumentów. Analizy oparte zostały na wynikach badań przeprowadzonych w 2014 roku na próbie 600 osób w wieku minimum 15 lat.

\section{Skuteczność oddziaływania reklamy a zachowania konsumentów}

Zachowania konsumenta na rynku rozpatrywane mogą być w wielu płaszczyznach. Następstwem tego jest wielość ujęć definicyjnych ${ }^{2}$. Definicje te zazwyczaj akcentują etapy wchodzące $\mathrm{w}$ skład procesu postępowania konsumenta lub dylematy decyzyjne związane z wyborem produktów. Przykładem może być koncepcja Engela, Blackwella i Miniarda, według której zachowania konsumenta definiować można jako ogół działań związanych z uzyskiwaniem, użytkowaniem i dysponowaniem dobrami oraz usługami wraz z decyzjami poprzedzającymi i warunkującymi te działania ${ }^{3}$, czy też Hansena, który poprzez zachowania konsumenta rozumie ogół działań i percepcji konsumenta składających się na przygotowanie decyzji wyboru produktu, dokonanie tego wyboru oraz konsumowanie ${ }^{4}$. Podobne ujęcia znaleźć można w literaturze polskojęzycznej ${ }^{5}$. Bez względu na podejście zwraca się uwagę na różnorodność czynników kształtujących zachowania konsumentów. Znalazło to wyraz w modelach zachowań konsumentów, których autorami byli m.in. Andreassen ${ }^{6}$, Nicosia ${ }^{7}$, Howard i Sheth ${ }^{8}$, czy też Engel, Kollat i Blackwell ${ }^{9}$. Wskazuje się w nich na istotne znaczenie procesów komunikacji rynkowej, w tym reklamy, definiowanej jako wszelka płatna forma nieosobowego przedstawiania i popierania towarów, usług lub idei przez określonego nadawcę ${ }^{10}$.

Zadaniem reklamy jest umyślne i dobrowolne oddziaływanie na nabywcę w celu skłonienia go do zachowań zgodnych z intencją nadawcy przekazu ${ }^{11}$, głównie związanych z motywowaniem do zakupu ${ }^{12}$. Realizacja celów reklamowych jest podstawą kształtowania jej skuteczności, rozumianej jako stopień realizacji postawionych przed reklamą celów komunikacyjnych, oraz efektywności, definiowanej w kontekście celów ekonomicznych jako stosunek finansowych korzyści związanych wynikających z prowadzenia działań reklamowych do nakładów z nią związanych ${ }^{13}$. Szczególnego znaczenia nabiera oddziaływanie związane z realizacją celów komunikacyjnych, które dotyczy

${ }^{2}$ G. Antonides, W.F. van Raaij, Zachowania konsumenta. Podręcznik akademicki, PWN, Warszawa 2003, s. 24; S. Smyczek, I. Sowa, Konsument na rynku. Zachowania, modele, aplikacje. Difin, Warszawa 2005, s. 61 oraz L. Rudnicki, Zachowania konsumentów na rynku, PWE, Warszawa 2012, s. 10-12.

${ }^{3}$ J.F. Engel, R.D. Blackwell, P.W. Miniard, Consumer behavior, Dryden Press, Chicago 1993, s. 4.

${ }^{4}$ F. Hansen, Consumer Choice Behavior. A Cognitive Theory, The Free Press, New York 1972, s. 15.

${ }^{5}$ Przykładem mogą być definicje zaprezentowane w pracach: J. Szczepański (red.), Badania nad wzorami konsumpcji, Ossolineum, Wrocław 1977, s. 23.; M. Pohorille, Mechanizmy i kierunki zmian w konsumpcji spoleczeństwa polskiego, UW, Warszawa 1980, s. 490.

${ }^{6}$ A.R. Andreasen, Attitudes and customer behavior, [w:] L.E. Preston (red.), New Research in Marketing, Institute of Business and Economic Research, University of California, Berkley 1965, s. 6.

${ }^{7}$ F.M. Nicosia, Consumer Decision Processes: Marketing and Advertising Implications, Prentice-Hall, Englewood Cliffs 1996.

${ }^{8}$ J.A. Howard, J.N. Sheth, The Theory of Buyer Behavior, Wiley, New York 1969.

${ }^{9}$ J.F. Engel, R.D. Blackwell, D.T. Kollat, Consumer behavior, Holt, Rinehart, and Winston, New York 1968

${ }^{10}$ G.E. Belch, M.A. Belch, Advertising and promotion. An integrated marketing comunications perspective, McGraw-Hill, New York 2009, s. 18.

${ }^{11}$ R. Nowacki, M. Strużycki, Reklama w przedsiębiorstwie, Difin, Warszawa 2002, s. 37.

${ }^{12}$ F. Jefkins, Advertising, Pitman Publishing, London 1985, s. 5.

${ }^{13}$ R. Nowacki, Reklama, Difin, Warszawa 2005, s. 176-177. 
optymalizacji działań reklamowych zarówno w krótkim, jak i w długim okresie ${ }^{14}$. Skuteczność reklamy rozpatrywać można przez pryzmat wpływania na wewnętrzne czynniki kształtujące zachowania konsumentów, takie jak potrzeby, motywy, postawy, czy preferencje, pamiętając, że odnosi się ona nie tylko do płaszczyzny ekonomicznej, marketingowej czy komunikacyjnej, ale też społecznej, kulturowej, religijnej czy politycznej ${ }^{15}$. W kontekście niniejszego opracowania oddziaływanie reklamy odnieść należy do dwóch podstawowych obszarów: percepcji i motywowania.

Percepcja związana jest z procesami poznawczymi, polegającymi na ciagłej wymianie informacji między organizmem a otoczeniem - $\mathrm{i}$ będącymi podstawą orientacji $\mathrm{w}$ otaczającym świecie ${ }^{16}$. Motywowanie jest siłą sprawczą, która skłania człowieka do podejmowania określonych działan związanych $\mathrm{z}$ zaspokajaniem potrzeb ${ }^{17}$. Reklama łączy w sobie te dwa procesy, dostarczając konsumentowi wiedzy o potrzebach i możliwościach ich zaspokajania oraz bodźców wywołujących motywację racjonalną, emocjonalną lub moralną. W ten sposób kreuje potrzeby i steruje ich zaspokajaniem, stając się czynnikiem wpływającym na zachowania konsumentów i podejmowane przez nich decyzje. Potwierdzają to badania poświęcone mechanizmom oddziaływania reklamy ${ }^{18}$.

W takim ujęciu o ocenie skuteczności oddziaływania reklamy decydują cztery kolejno następujące po sobie fazy (rysunek 1):

- ocena atrakcyjności reklamy, czyli jej subiektywnie postrzeganej zdolności przyciągania uwagi w sposób umożliwiający zapoznanie się z treścią, rozpatrywana w kategoriach podobania się przekazu lub nie ${ }^{19}$,

- ocena wiarygodności reklamy, czyli postrzeganie przekazywanych w przekazie reklamowym treści jako prawdziwych, utożsamiana $\mathrm{z}$ budzeniem zaufania do nadawcy przekazu i promowanych przez niego produktów lub idei ${ }^{20}$,

- ocena zachęcania do działania propagowanego przez nadawcę reklamy, czyli pobudzanie motywów aktywizujących i ukierunkowujących działanie odbiorcy na osiągnięcie celu motywowania do zakupu ${ }^{21}$,

- ocena rzeczywistej akcji podjętej przez odbiorce pod wpływem komunikatu reklamowego, czyli przełożenie postawy ukształtowanej w wyniku wcześniejszych faz na zachowanie (np. zakup reklamowanego produktu) ${ }^{22}$.

\footnotetext{
${ }^{14}$ R. Nowacki, Procesy zarzqdzania działalnościq reklamowq $w$ przedsiębiorstwach, [w:] R. Nowacki, M. Strużycki (red.), Reklama w procesach konkurencji, Difin, Warszawa 2011, s. 108.

${ }^{15} \mathrm{R}$. Nowacki, Ustugi reklamowe $w$ procesie ksztaltowania pozycji rynkowej przedsiębiorstw - skala $i$ perspektywy wykorzystania, „Handel Wewnętrzny”, 4/2016, s. 175.

${ }^{16}$ A. Jachnis, J.F. Terelak, Psychologia konsumenta i reklamy, Branta, Bydgoszcz 1998, s. 67.

${ }^{17}$ A. Falkowski, T. Tyszka, Psychologia zachowań konsumenckich, GWP, Gdańsk 2001, s. 59.

${ }^{18}$ Szerzej na temat badań percepcji reklamy traktuje m.in. pozycja: A. Jachnis, J.F. Terelak, Psychologia konsumenta i reklamy, Oficyna Wydawnicza Branta, Bydgoszcz 1998.

${ }^{19}$ R. Nowacki, M. Strużycki, Reklama w przedsiębiorstwie, Difin, Warszawa 2002, s. 65.

${ }^{20}$ A. Kozłowska, Bohater reklamowy, czyli jak budować wiarygodność w reklamie, „Kwartalnik Kolegium Ekonomiczno-Społecznego Studia i Prace / Szkoła Główna Handlowa”, 2013, nr 1, s. 120. Zob. również: M. Eisend, Source Credibility Dimensions in Marketing Communication - A Generalized Solution, ,Journal of Empirical Generalisations in Marketing", 2/2006, oraz R. Adler, G. Rodman, Understanding Human Communication, Oxford University Press, New York 2000

${ }^{21}$ C.L. Bovee, W.F. Arens, Contemporary Advertising, Irwin, Homewood 1983, s. 151.

${ }^{22}$ A. Kozłowska, Reklama. Techniki perswazyjne, Oficyna Wydawnicza SGH 2011, s. 280.
} 


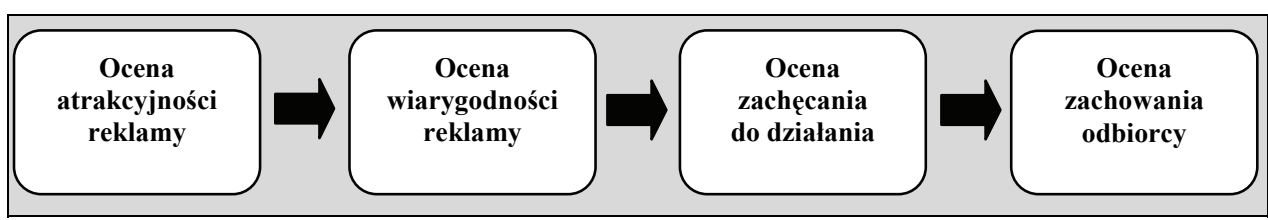

Rysunek 1. Schemat skuteczności oddziaływania reklamy Źródło: opracowanie własne.

\section{Metodyka badania}

Problematyka oceny reklamy artykułów żywnościowych była przedmiotem badań przeprowadzonych w 2014 roku. Badania zrealizowane zostały na ogólnopolskiej próbie 600 osób powyżej 15 roku życia, dobranej w sposób reprezentatywny pod względem płci, wieku i miejsca zamieszkania. Badanie przeprowadzono metodą wywiadów bezpośrednich na podstawie autorskiego kwestionariusza. Charakterystykę badanej populacji przedstawia tabela 1 .

Tabela 1. Charakterystyka badanej populacji

\begin{tabular}{|c|c|c|c|}
\hline & Wyszczególnienie & $\begin{array}{c}\text { Liczba } \\
\text { badanych }\end{array}$ & $\begin{array}{c}\text { Procent } \\
\text { badanych }\end{array}$ \\
\hline \multicolumn{2}{|l|}{ Ogółem } & 600 & 100,0 \\
\hline \multirow{2}{*}{ Płeć } & Kobieta & 307 & 51,2 \\
\hline & Mężczyzna & 293 & 48,8 \\
\hline \multirow{6}{*}{ Wiek } & $15-24$ & 108 & 18,0 \\
\hline & $25-34$ & 123 & 20,5 \\
\hline & $35-44$ & 97 & 16,2 \\
\hline & $45-54$ & 107 & 17,8 \\
\hline & $55-64$ & 100 & 16,7 \\
\hline & 65 i więcej & 65 & 10,8 \\
\hline \multirow{4}{*}{ Wykształcenie } & Podstawowe, gimnazjalne & 47 & 7,8 \\
\hline & Zasadnicze zawodowe & 139 & 23,2 \\
\hline & Średnie, policealne & 255 & 42,5 \\
\hline & Wyższe & 159 & 26,5 \\
\hline \multirow{3}{*}{$\begin{array}{l}\text { Miejsce zamiesz- } \\
\text { kania }\end{array}$} & Wieś & 237 & 39,5 \\
\hline & Miasto do 50 tys. mieszkańców & 187 & 31,2 \\
\hline & Miasto pow. 50 tys. mieszkańców & 176 & 29,3 \\
\hline \multirow{15}{*}{ Województwo } & Dolnośląskie & 45 & 7,5 \\
\hline & Kujawsko-pomorskie & 33 & 5,5 \\
\hline & Lubelskie & 34 & 5,7 \\
\hline & Lubuskie & 16 & 2,7 \\
\hline & Łódzkie & 40 & 6,7 \\
\hline & Mazowieckie & 83 & 13,8 \\
\hline & Podlaskie & 19 & 3,2 \\
\hline & Podkarpackie & 33 & 5,5 \\
\hline & Pomorskie & 35 & 5,8 \\
\hline & Opolskie & 16 & 2,7 \\
\hline & Śląskie & 74 & 12,3 \\
\hline & Świętokrzyskie & 20 & 3,3 \\
\hline & Warmińsko-mazurskie & 22 & 3,7 \\
\hline & Wielkopolskie & 53 & 8,8 \\
\hline & Zachodniopomorskie & 26 & 4,3 \\
\hline
\end{tabular}

Źródło: badanie własne, 2014 
W obszarze zagadnień związanych z odbiorem działań reklamowych i ich skuteczności analizie poddano kwestie oceny atrakcyjności i wiarygodności reklamy, jej zdolności do motywowania do zakupu, a także deklaracje dotyczące kupowania pod jej wpływem. We wszystkich obszarach problemowych pytania odniesiono do jedenastu kategorii artykułów żywnościowych: napojów bezalkoholowych, napojów alkoholowych, piwa, używek, słodyczy, mięsa i wędlin, nabiału, pieczywa, koncentratów spożywczych, gum do żucia oraz innych artykułów spożywczych.

W analizie wykorzystano istotne statystycznie wskaźniki struktury oraz miary korelacji pomiędzy zmiennymi. Zależności pomiędzy zmiennymi niezależnymi (objaśniającymi) a zależnymi (objaśnianymi) określono na podstawie testu nieparametrycznego chikwadrat, a siłę zidentyfikowanych zależności wyznaczono przy pomocy współczynnika V-Cramera. Wyniki analiz zaprezentowane zostały z uwzględnieniem zróżnicowania na trzy podstawowe kategorie demograficzne (płeć, wiek i wykształcenie), miejsce zamieszkania oraz zmienną określającą kupowanie lub nie artykułów żywnościowych pod wpływem reklamy.

\section{Postrzeganie charakteryzujących reklamę artykułów żywnościowych w świetle wyników badania}

Wyniki badania wskazują, że reklamy żywności oceniane były generalnie jako atrakcyjne. Opinię taką podzielało $61,5 \%$ badanych. Z punktu widzenia poszczególnych kategorii produktów żywnościowych najczęściej za atrakcyjne uznane zostały przekazy reklamowe piwa (22,5\% wskazań), a w dalszej kolejności słodyczy (15,7\%), używek $(15,0 \%)$, nabiału $(13,3 \%)$, napojów bezalkoholowych $(11,8 \%)$ oraz alkoholi $(11,7 \%)$.

W poszczególnych przekrojach korelacyjnych dostrzec można przy tym pewne różnice $\mathrm{w}$ tym zakresie. I tak w przypadku płci zwraca uwagę nieco większa skłonność oceniania reklam jako atrakcyjnych - dotyczy to siedmiu $\mathrm{z}$ analizowanych kategorii, $\mathrm{w}$ tym w największym stopniu różnica występuje w odniesieniu do piwa, używek i napojów bezalkoholowych. Kobiety natomiast zdecydowanie częściej wskazywały na atrakcyjność reklam słodyczy i nabiału. Mniejsze różnice wystąpiły w przypadku wieku. Zwrócić należy jedynie uwagę na fakt, że im młodsi badani, tym bardziej podobały im się reklamy alkoholi. Pozytywna ocena atrakcyjności reklam była też pochodną rosnącego poziomu wykształcenia. Podobny kierunek dotyczył też zależności pomiędzy wskaźnikami podobania się reklam większości artykułów żywnościowych a miejscem zamieszkania - rosły one wraz ze wzrostem wielkości miejscowości. Interesująca zależność wystąpiła w przypadku zmiennej charakteryzującej podatność na oddziaływanie reklamy w kontekście dokonywanych zakupów. W przypadku ośmiu analizowanych kategorii produktowych fakt kupowania żywności pod wpływem reklamy dodatnio wpływał na postrzeganie jej jako atrakcyjnej. Odwrotna relacja wystąpiła natomiast w odniesieniu do trzech kategorii - mięso i wędliny, nabiał oraz pieczywo - wyraźnie częściej ich reklamy jako atrakcyjne oceniały osoby nie biorące w procesach zakupowych pod uwagę działań reklamowych (tabela 2). 
Tabela 2. Produkty żywnościowe najbardziej atrakcyjnie reklamowane w opinii badanych respondentów, \% wskazań ( $\mathrm{N}=600)$

\begin{tabular}{|c|c|c|c|c|c|c|c|c|c|c|c|}
\hline $\begin{array}{c}\text { Wyszczególnie- } \\
\text { nie }\end{array}$ & 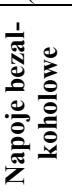 & 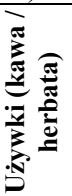 & $\stackrel{\sum}{i}$ & 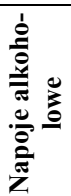 & $\begin{array}{l}\frac{8}{8} \\
\frac{\pi}{0} \\
\frac{\pi}{\omega}\end{array}$ & 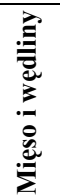 & 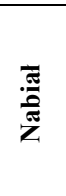 & 葛 & 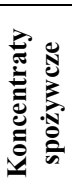 & 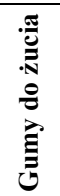 & 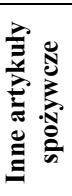 \\
\hline Ogólem & 11,8 & 15,0 & 22,5 & 11,7 & 15,7 & 7,7 & 13,3 & 7,5 & 2,0 & 6,7 & 2,3 \\
\hline \multicolumn{12}{|c|}{ Pleć } \\
\hline Kobieta & 9,8 & 10,4 & 16,0 & 9,4 & 18,6 & 6,8 & 16,6 & 8,8 & 2,0 & 5,5 & 2,3 \\
\hline Mężczyzna & 14,0 & 19,8 & 29,4 & 9,9 & 12,6 & 8,5 & 9,9 & 6,1 & 2,0 & 7,8 & 2,4 \\
\hline \multicolumn{12}{|c|}{ Wiek } \\
\hline $15-24$ & 13,0 & 14,8 & 8,5 & 16,7 & 22,2 & 3,7 & 0,2 & 7,4 & 1,9 & 13,0 & - \\
\hline 25 & 17.9 & 13,0 & 24,4 & 12,2 & 14,6 & 2,4 & 9 & 3,3 & 4.9 & 8,1 & 4.1 \\
\hline $35-2$ & 7,2 & 12,4 & 28,9 & 10,3 & 11,3 & 10,3 & 14,4 & 0,3 & 1,0 & 3,1 & 1,0 \\
\hline $45-5$ & 10,3 & 18,7 & 20,6 & 8,4 & 13,1 & 11,2 & 7,8 & 11,2 & 1,9 & 5,6 & 3,7 \\
\hline $55-64$ & 9,0 & 18,0 & 20,0 & 4,0 & 20,0 & 8,0 & 12,0 & 2,0 & 1,0 & 7,0 & 3,0 \\
\hline 65 i wię & 12,3 & 12,3 & 23,1 & 3,1 & 10,8 & 13,8 & 20,0 & 13,8 & - & - & 1,5 \\
\hline \multicolumn{12}{|c|}{ Wyksztalcenie } \\
\hline $\begin{array}{l}\text { Podstawowe, } \\
\text { gimnazjalne }\end{array}$ & 4,3 & 2,1 & 8,5 & 8,5 & 19,1 & 6,4 & 2,1 & 4,3 & - & 6,4 & 2,1 \\
\hline $\begin{array}{l}\text { Zasadnicze } \\
\text { zawodowe }\end{array}$ & 12,2 & 21,6 & 23,7 & 8,6 & 12,2 & 9,4 & 11,5 & 6,5 & 1,4 & 5,8 & 5,0 \\
\hline $\begin{array}{l}\text { Srednie, police- } \\
\text { alne }\end{array}$ & 10,6 & 14,5 & 22,4 & 7,8 & 17,3 & 7,8 & 12,9 & 7,8 & 2,0 & 8,6 & 8 \\
\hline Wyższe & 15,7 & 13,8 & 25,8 & 13,8 & 15,1 & 6,3 & 18,9 & 8,8 & 3,1 & 4,4 & 2,5 \\
\hline \multicolumn{12}{|c|}{ Miejsce zamieszkania } \\
\hline Wieś & 8,0 & 14,3 & 18,6 & 9,3 & 14,8 & 7,2 & 5,1 & 4,6 & 2,5 & 4,2 & 1,7 \\
\hline Miasto do 50 tys. & 14,4 & 17,6 & 24,6 & 9,1 & 17,6 & 9,6 & 18,7 & 8,0 & 1,1 & 5,3 & 1,6 \\
\hline $\begin{array}{l}\text { Miasto pow. } 50 \\
\text { tys. }\end{array}$ & 14,2 & 13,1 & 25,6 & 10,8 & 14,8 & 6,3 & 18,8 & 10,8 & 2,3 & 11,4 & 4,0 \\
\hline \multicolumn{12}{|c|}{ Podatność na reklamę żywnoś } \\
\hline Nie, nie kupuję & 10,0 & 11,6 & 19,7 & 6,0 & 12,5 & 11,6 & 19,1 & 10,7 & 1,9 & 4,1 & 1,3 \\
\hline Tak kupuję & 13,9 & 18,9 & 25,6 & 13,9 & 19,2 & 3,2 & 6,8 & 3,9 & 2,1 & 9,6 & 3,6 \\
\hline
\end{tabular}

Źródło: badanie własne, 2014.

Badani w nieco wyższym stopniu niż atrakcyjność ocenili wiarygodność przekazów reklamujących artykuły żywnościowe - 63,3\% z nich zadeklarowało zaufanie wobec takich komunikatów. Inaczej przedstawiała się natomiast hierarchia najbardziej wiarygodnie reklamowanych branż. W tym ujęciu najczęściej wskazywano na napoje bezalkoholowe $(21,7 \%)$, używki $(19,2 \%)$ oraz piwo $(16,7 \%)$. Dwie pierwsze z wymienionych branż odnotowały przy tym dodatnie saldo różnic pomiędzy ocenami wiarygodności a atrakcyjności. W przypadku piwa (a także m.in. słodyczy i nabiału) wystąpiła sytuacja odwrotna - częściej reklamy się podobają, ale nie są uznawane za godne zaufania.

Uwidoczniły się przy tym pewne różni ce w ocenie wiarygodności z punktu widzenia zmiennych charakteryzujących osoby badane. Częściej pozytywnie oceniają wiarygodność reklam żywności kobiety (w przypadku ośmiu kategorii wskaźniki były wyższe niż w przypadku mężczyzn). Generalnie większym krytycyzmem wykazali się w tym kontekście badani należący do starszych grup wiekowych, a także lepiej wykształceni (choć w tym przypadku różnice były znacznie mniejsze). Zdecydowanie spłaszczyły się natomiast dysproporcje w przypadku miejsca zamieszkania respondentów. Utrzymała się 
tendencje $\mathrm{w}$ odniesieniu do podatności na działanie reklamy - w tych samych trzech kategoriach produktowych wyższe wskaźniki dotyczyły grupy nie kupujących pod wpływem reklamy, ale różnice były już niższe (tabela 3).

Tabela 3. Produkty żywnościowe najbardziej wiarygodnie reklamowane w opinii badanych respondentów, w \% wskazań $(\mathrm{N}=600)$

\begin{tabular}{|c|c|c|c|c|c|c|c|c|c|c|c|}
\hline $\begin{array}{c}\text { Wyszczególnie- } \\
\text { nie }\end{array}$ & 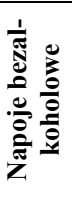 & 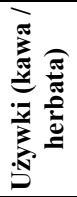 & $\sum_{i}$ & 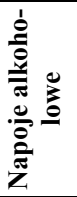 & 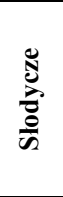 & 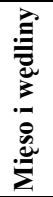 & $\begin{array}{l}\frac{\vec{\pi}}{0} \\
\frac{\pi}{\pi} \\
\text { Z }\end{array}$ & 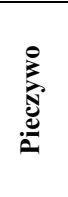 & 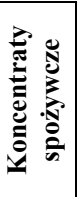 & 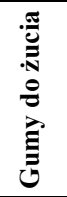 & 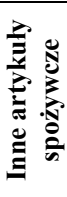 \\
\hline Ogółem & 21,7 & 19,2 & 16,7 & 13,7 & 12,2 & 8,7 & 8,2 & 7,7 & 5,8 & 5,3 & 3,0 \\
\hline \multicolumn{12}{|c|}{ Płeć } \\
\hline Kobieta & 8,1 & 23,1 & 13,0 & 8,5 & 18,6 & 4,6 & 13,7 & 10,1 & 5,2 & 6,8 & 3,9 \\
\hline Mężczyzna & 16,4 & 20,1 & 25,6 & 7,8 & 14,7 & 6,1 & 13,7 & 7,2 & 6,5 & 8,5 & 2,0 \\
\hline \multicolumn{12}{|c|}{ Wiek } \\
\hline $15-24$ & 18,5 & 25,0 & 22,2 & 5,6 & 24,1 & 4,6 & 9,3 & 1,9 & 2,8 & 16,7 & ,9 \\
\hline $25-34$ & 11,4 & 21,1 & 16,3 & 12,2 & 17,9 & 5,7 & 14,6 & 8,9 & 4,9 & 8,1 & 4,1 \\
\hline $35-44$ & 8,2 & 22,7 & 19,6 & 10,3 & 12,4 & 6,2 & 13,4 & 5,2 & 3,1 & 9,3 & 3,1 \\
\hline $45-54$ & 9,3 & 17,8 & 15,9 & 7,5 & 19,6 & 5,6 & 15,0 & 15,0 & 7,5 & 4,7 & 2,8 \\
\hline $55-64$ & 17,0 & 25,0 & 19,0 & 8,0 & 12,0 & 5,0 & 13,0 & 10,0 & 10,0 & 3,0 & 5,0 \\
\hline 65 i więcej & 6,2 & 16,9 & 24,6 & 3,1 & 10,8 & 4,6 & 18,5 & 12,3 & 7,7 & 1,5 & 1,5 \\
\hline \multicolumn{12}{|c|}{ Wykształcenie } \\
\hline $\begin{array}{l}\text { Podstawowe, } \\
\text { gimnazjalne }\end{array}$ & 2,1 & 23,4 & 21,3 & 4,3 & 23,4 & - & 8,5 & 8,5 & 12,8 & 12,8 & 6,4 \\
\hline $\begin{array}{l}\text { Zasadnicze } \\
\text { zawodowe }\end{array}$ & 18,0 & 23,0 & 29,5 & 11,5 & 18,7 & 7,9 & 15,1 & 9,4 & 7,2 & 7,2 & 3,6 \\
\hline $\begin{array}{l}\text { Średnie, police- } \\
\text { alne }\end{array}$ & 12,9 & 23,5 & 13,7 & 7,5 & 17,3 & 5,5 & 14,5 & 8,6 & 4,3 & 7,5 & 1,2 \\
\hline Wyższe & 8,8 & 17,0 & 18,2 & 7,5 & 11,9 & 4,4 & 12,6 & 8,2 & 5,0 & 6,9 & 4,4 \\
\hline \multicolumn{12}{|c|}{ Miejsce zamieszkania } \\
\hline Wieś & 10,1 & 19,8 & 21,9 & 8,9 & 14,8 & 4,6 & 15,2 & 8,9 & 5,5 & 11,0 & 2,1 \\
\hline Miasto do 50 tys. & 13,9 & 23,5 & 11,2 & 5,9 & 19,8 & 6,4 & 12,3 & 7,0 & 6,4 & 5,9 & 4,3 \\
\hline $\begin{array}{l}\text { Miasto pow. } 50 \\
\text { tys. }\end{array}$ & 13,1 & 22,2 & 23,9 & 9,7 & 15,9 & 5,1 & 13,1 & 10,2 & 5,7 & 5,1 & 2,8 \\
\hline \multicolumn{12}{|c|}{ Podatność na reklamę żywności } \\
\hline Nie, nie kupuję & 8,8 & 14,1 & 15,0 & 8,5 & 9,7 & 6,0 & 14,7 & 11,0 & 4,1 & 3,1 & 2,2 \\
\hline Tak kupuję & 16,0 & 30,2 & 23,8 & 7,8 & 24,6 & 4,6 & 12,5 & 6,0 & 7,8 & 12,8 & 3,9 \\
\hline
\end{tabular}

Źródło: badanie własne, 2014.

Na tle wysokich wskaźników atrakcyjności i wiarygodności reklamy artykułów żywnościowych gorzej przedstawia się sytuacja w zakresie jej motywowania do zakupu. Odsetek osób deklarujących, że zachęca ona do kupna reklamowanych produktów wyniósł jedynie 45,5\%. Jedynie w przypadku dwóch kategorii produktowych odnotowano przy tym wskaźniki przekraczające $10 \%-17,0 \% \mathrm{w}$ przypadku słodyczy oraz $15,2 \% \mathrm{w}$ przypadku piwa. Niższe wskaźniki odnotowano w przypadku dwóch kategorii uznanych za najbardziej wiarygodnie reklamowane - napoje bezalkoholowe oraz używki (odpowiednio $8,0 \%$ oraz 9,7\%). Kategoria słodyczy (oraz dodatkowo pozycja inne artykuły spożywcze) uzyskała natomiast wyższą ocenę w zakresie zachęcania do zakupu niż w odniesieniu do wiarygodności. 
Podobnie jak w przypadku zaufania do reklam, na zachęcanie do zakupu nieco częściej wskazują kobiety. W przekroju wiekowym wyraźnie negatywnie oceniają tę cechę przekazów reklamowych dotyczących żywności osoby w najstarszej grupie wiekowej (przy generalnie mało zróżnicowanych - poza słodyczami, gdzie wyraź widać, że im młodsi badani, tym bardziej dostrzegają motywujący charakter przekazu - ocenach w innych grupach). Chętniej natomiast doceniają zachęcający charakter reklamy osoby o niższym wykształceniu oraz zamieszkujący większe miasta. W kontekście podatności na reklamę uwidoczniła się zdecydowanie lepsza ocena osób kupujących żywność pod wpływem reklamy - dotyczyło to każdej z analizowanych kategorii produktowych (tabela 4).

Tabela 4. Produkty żywnościowe, których reklamy najbardziej zachęcają do zakupu w opinii badanych respondentów, w \% wskazań $(\mathrm{N}=600)$

\begin{tabular}{|c|c|c|c|c|c|c|c|c|c|c|c|}
\hline $\begin{array}{c}\text { Wyszczególnie- } \\
\text { nie }\end{array}$ & 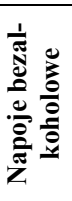 & 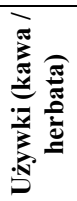 & $\sum_{i=1}$ & 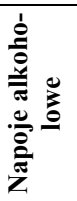 & 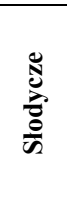 & 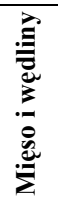 & 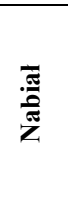 & 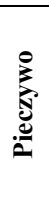 & 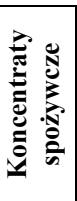 & 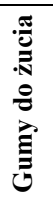 & 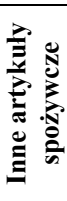 \\
\hline Ogólem & 8,0 & 9,7 & 15,2 & 6,5 & 17,0 & 3,7 & 7,5 & 2,5 & 0,5 & 4,0 & 3,5 \\
\hline \multicolumn{12}{|c|}{ Pleć } \\
\hline Kobieta & 7,2 & 10,4 & 11,4 & 6,2 & 20,8 & 4,6 & 7,8 & 1,3 & ,3 & 4,2 & 3,6 \\
\hline Mężczyzna & 8,9 & 8,9 & 19,1 & 6,8 & 13,0 & 2,7 & 7,2 & 3,8 &, 7 & 3,8 & 3,4 \\
\hline \multicolumn{12}{|c|}{ Wiek } \\
\hline $15-24$ & 8,3 & 11,1 & 21,3 & 7,4 & 25,0 & 1,9 & 3,7 & 1,9 & - & 9,3 & 4,6 \\
\hline $25-34$ & 6,5 & 4,9 & 7,3 & 6,5 & 15,4 & 4,1 & 10,6 & 2,4 & ,8 & 5,7 & 4,1 \\
\hline $35-44$ & 8,2 & 11,3 & 20,6 & 11,3 & 19,6 & 5,2 & 6,2 & 3,1 & - & 2,1 & 1,0 \\
\hline $45-54$ & 12,1 & 13,1 & 14,0 & 9,3 & 15,9 & 7,5 & 5,6 & 2,8 & - & - & 4,7 \\
\hline $55-64$ & 8,0 & 12,0 & 14,0 & 1,0 & 15,0 & - & 8,0 & & 2,0 & 4,0 & 5,0 \\
\hline 65 i więcej & 3,1 & 4,6 & 15,4 & 1,5 & 7,7 & 3,1 & 12,3 & 6,2 & & 1,5 & - \\
\hline \multicolumn{12}{|c|}{ Wykształcenie } \\
\hline $\begin{array}{l}\text { Podstawowe, } \\
\text { gimnazjalne }\end{array}$ & 8,5 & 6,4 & 12,8 & 8,5 & 21,3 & - & - & - & - & 4,3 & 6,4 \\
\hline $\begin{array}{l}\text { Zasadnicze } \\
\text { zawodowe }\end{array}$ & 9,4 & 9,4 & 15,1 & 11,5 & 17,3 & 2,2 & 3,6 & 2,9 & - & 7,2 & 2,2 \\
\hline $\begin{array}{l}\text { Srednie, police- } \\
\text { alne }\end{array}$ & 6,3 & 12,2 & 14,9 & 4,7 & 16,9 & 4,3 & 9,4 & 2,0 & - & 3,1 & 2,7 \\
\hline Wyższe & 9,4 & 6,9 & 16,4 & 4,4 & 15,7 & 5,0 & 10,1 & 3,8 & 1,9 & 2,5 & 5,0 \\
\hline \multicolumn{12}{|c|}{ Miejsce zamieszkania } \\
\hline Wieś & 8,9 & 9,3 & 13,1 & 7,2 & 17,7 & 2,1 & 5,1 & ,8 & ,4 & 2,5 & 1,7 \\
\hline Miasto do 50 tys. & 5,3 & 12,3 & 10,7 & 4,8 & 15,5 & 2,7 & 9,1 & 3,7 &, 5 & 6,4 & 3,2 \\
\hline $\begin{array}{l}\text { Miasto pow. } 50 \\
\text { tys. }\end{array}$ & 9,7 & 7,4 & 22,7 & 7,4 & 17,6 & 6,8 & 9,1 & 3,4 & 6 & 3,4 & 6,3 \\
\hline \multicolumn{12}{|c|}{ Podatność na reklamę żywności } \\
\hline Nie, nie kupuję & 4,1 & 4,1 & 9,7 & 5,0 & 6,3 & 3,8 & 5,3 & 1,6 & 0,3 & 0,9 & 0,9 \\
\hline Tak kupuję & 12,5 & 16,0 & 21,4 & 8,2 & 29,2 & 3,6 & 10,0 & 3,6 & 0,7 & 7,5 & 6,4 \\
\hline
\end{tabular}

Źródło: badanie własne, 2014.

Spośród osób tworzących badaną grupę ponad połowa - 53,2\% - zadeklarowała kupowanie produktów żywnościowych pod wpływem reklamy. Najczęściej kupowane pod wpływem reklamy były słodycze - przyznała się do tego co piąta badana osoba. Kilkunastoprocentowe wskaźniki kupowania wystapiły ponadto w przypadku używek, 
napojów bezalkoholowych i piwa. W przypadku pozostałych grup odsetki wskazań nie przekraczają 10\%. Pod wpływem reklam żywność kupują przede wszystkim kobiety jedynie w przypadku piwa oraz mięsa i wędlin częściej czynią to mężczyźni. Zazwyczaj są to zachowania charakterystyczne dla młodszych grup wiekowych - w dziewięciu na jedenaście przypadków najwyższe odsetki kupujących dotyczą dwóch najniższych przedziałów wiekowych - i osób z niższym poziomem wykształcenia - tylko raz, w przypadku gum do żucia najwyższy odsetek, wystapił wśród badanych z wykształceniem wyższym. Najmniej podatni na działanie reklam są natomiast mieszkańcy terenów wiejskich - choć w przypadku tego kryterium różnice pomiędzy poszczególnymi grupami badanych były bardzo małe (tabela 5 ).

Tabela 5. Produkty żywnościowe kupowane przez badanych respondentów pod wpływem reklamy, w \% wskazań $(\mathrm{N}=600)$

\begin{tabular}{|c|c|c|c|c|c|c|c|c|c|c|c|}
\hline $\begin{array}{c}\text { Wyszczególnie- } \\
\text { nie }\end{array}$ & 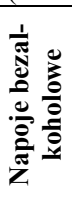 & 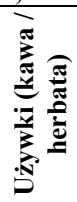 & $\sum_{i=1}^{0}$ & 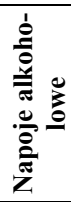 & $\frac{\tilde{S}}{\frac{8}{0}}$ & 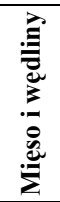 & $\begin{array}{l}\overline{\bar{\pi}} \\
\frac{\bar{n}}{\bar{n}} \\
\bar{z}\end{array}$ & : & 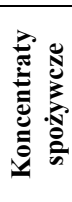 & 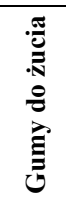 & 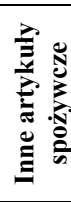 \\
\hline Ogólem & 14,3 & 16,7 & 14,3 & 5,0 & 20,5 & 2,8 & 8,3 & 2,7 & 3,3 & 9,2 & 7,2 \\
\hline \multicolumn{12}{|c|}{ Pleć } \\
\hline Kobieta & 14,7 & 20,2 & 9,4 & 5,5 & 23,8 & 2,6 & 10,7 & 3,3 & 4,2 & 10,4 & 9,1 \\
\hline Mężczyzna & 14,0 & 13,0 & 18,1 & 4,4 & 17,1 & 3,1 & 5,8 & 2,0 & 2,4 & 7,8 & 5,1 \\
\hline \multicolumn{12}{|c|}{ Wiek } \\
\hline $15-24$ & 26,9 & 23,1 & 15,7 & 7,4 & 36,1 & 4,6 & 8,3 & 2,8 & 1,9 & 22,2 & 6,5 \\
\hline $25-34$ & 20,3 & 14,6 & 17,9 & 10,6 & 19,5 & 5,7 & 9,8 & 4,9 & 3,3 & 7,3 & 8,9 \\
\hline $35-44$ & 9,3 & 19,6 & 12,4 & 3,1 & 21,6 & 1,0 & 9,3 & 2,1 & 3,1 & 10,3 & 8,2 \\
\hline $45-54$ & 6,5 & 16,8 & 8,4 & 1,9 & 13,1 & 1,9 & 5,6 & 2,8 & 1,9 & 4,7 & 4,7 \\
\hline $55-64$ & 9,0 & 14,0 & 11,0 & 1,0 & 17,0 & - & 12,0 & 2,0 & 7,0 & 6,0 & 8,0 \\
\hline 65 i więcej & 10,8 & 9,2 & 16,9 & 4,6 & 12,3 & 3,1 & 3,1 & - & 3,1 & 1,5 & 6,2 \\
\hline \multicolumn{12}{|c|}{ Wykształcenie } \\
\hline $\begin{array}{l}\text { Podstawowe, } \\
\text { gimnazjalne }\end{array}$ & 12,8 & 10,6 & 14,9 & 4,3 & 23,4 & - & 2,1 & - & 10,6 & 10,6 & 12,8 \\
\hline $\begin{array}{l}\text { Zasadnicze } \\
\text { zawodowe }\end{array}$ & 14,4 & 10,1 & 14,4 & 5,8 & 17,3 & 4,3 & 5,0 & 1,4 & 3,6 & 5,8 & 6,5 \\
\hline $\begin{array}{l}\text { Średnie, police- } \\
\text { alne }\end{array}$ & 16,9 & 20,4 & 12,5 & 5,1 & 22,0 & 3,1 & 11,4 & 3,9 & 2,4 & 9,8 & 7,1 \\
\hline Wyższe & 10,7 & 18,2 & 14,5 & 4,4 & 20,1 & 1,9 & 8,2 & 2,5 & 2,5 & 10,7 & 6,3 \\
\hline \multicolumn{12}{|c|}{ Miejsce zamieszkania } \\
\hline Wieś & 13,5 & 15,6 & 16,0 & 5,1 & 20,3 & 2,5 & 8,0 & 1,7 & 2,1 & 8,0 & 5,1 \\
\hline Miasto do 50 tys. & 15,5 & 18,2 & 9,6 & 5,9 & 20,9 & 3,7 & 7,5 & 2,1 & 4,8 & 9,1 & 7,5 \\
\hline $\begin{array}{l}\text { Miasto pow. } 50 \\
\text { tys. }\end{array}$ & 14,2 & 16,5 & 14,8 & 4,0 & 20,5 & 2,3 & 9,7 & 4,5 & 3,4 & 10,8 & 9,7 \\
\hline \multicolumn{12}{|c|}{ Podatność na reklamę żywności } \\
\hline Nie, nie kupuję & - & - & - & - & - & - & - & - & - & - & - \\
\hline Tak kupuję & 30,6 & 35,6 & 29,2 & 10,7 & 43,8 & 6,0 & 17,8 & 5,7 & 7,1 & 19,6 & 15,3 \\
\hline
\end{tabular}

Źródło: badanie własne, 2014.

Charakteryzując postrzeganie atrybutów charakteryzujących reklamę artykułów żywnościowych poddano również analizie zależność pomiędzy ich oceną a zmiennymi opisującymi badaną zbiorowość (tabela 6). Wykorzystanie w tym celu testu nieparametrycznego chi-kwadrat przy przyjętym współczynniku ufności $\alpha=0,05$ wykazało wystę- 
powanie statystycznie istotnej zależności w sześciu z dziewiętnastu możliwych przypadków (po pięć w przypadku oceny atrakcyjności, wiarygodności i zachęcania do zakupu oraz czterech dla kupowania pod wpływem reklamy).

Tabela 6. Ocena zależności pomiędzy percepcją reklamy artykułów żywnościowych a podatnością na reklamę żywności

\begin{tabular}{|c|c|c|c|c|c|}
\hline Wyszczególnienie & $\begin{array}{c}\text { Chi- } \\
\text { kwadrat } \\
\chi^{2} \\
\end{array}$ & Df & $\begin{array}{c}\text { Istotność } \\
\text { asymptotyczna } \\
\text { (dwustronna) }\end{array}$ & $\begin{array}{c}\text { Wspólczyn- } \\
\text { nik } \\
\text { V-Cramera } \\
\end{array}$ & $\begin{array}{c}\text { Decyzja } \\
\text { o zależności przy } \alpha \\
=0,05\end{array}$ \\
\hline \multicolumn{6}{|c|}{ Reklama artykulów żywnościowych jest atrakcyjna } \\
\hline Płeć & 0,650 & 1 & 0,420 & 0,033 & Nieistotna \\
\hline Wiek & 4,474 & 5 & 0,483 & 0,086 & Nieistotna \\
\hline Wykształcenie & 2,783 & 3 & 0,426 & 0,068 & Nieistotna \\
\hline Miejsce zamieszkania & 8,5291 & 2 & 0,014 & 0,119 & Istotna, słaba \\
\hline Podatność na reklamę & 15,196 & 1 & 0,000 & 0,159 & Istotna, słaba \\
\hline \multicolumn{6}{|c|}{ Reklama artykułów żywnościowych jest wiarygodna } \\
\hline Płeć & 0,565 & 1 & 0,452 & 0,031 & Nieistotna \\
\hline Wiek & 5,324 & 5 & 0,378 & 0,094 & Nieistotna \\
\hline Wykształcenie & 11,656 & 3 & 0,009 & 0,139 & Istotna, słaba \\
\hline Miejsce zamieszkania & 2,541 & 2 & 0,281 & 0,065 & Nieistotna \\
\hline Podatność na reklamę & 33,386 & 1 & 0,000 & 0,236 & Istotna, słaba \\
\hline \multicolumn{6}{|c|}{ Reklama artykułów żywnościowych jest zachęcająca do zakupu } \\
\hline Płeć & 0,013 & 1 & 0,911 & 0,005 & Nieistotna \\
\hline Wiek & 9,894 & 5 & 0,078 & 0,128 & Nieistotna \\
\hline Wykształcenie & 1,023 & 3 & 0,796 & 0,041 & Nieistotna \\
\hline Miejsce zamieszkania & 2,532 & 2 & 0,282 & 0,065 & Nieistotna \\
\hline Podatność na reklamę & 140495 & 1 & 0,000 & 0,484 & Istotna, dość silna \\
\hline \multicolumn{6}{|c|}{ Kupuję artykuły żywnościowe pod wpływem reklamy } \\
\hline Płeć & 0,730 & 1 & 0,393 & 0,035 & Nieistotna \\
\hline Wiek & 19,742 & 5 & 0,001 & 0,181 & Istotna, słaba \\
\hline Wykształcenie & 5,189 & 3 & 0,158 & 0,093 & Nieistotna \\
\hline Miejsce zamieszkania & 1,804 & 2 & 0,406 & 0,055 & Nieistotna \\
\hline
\end{tabular}

Źródło: badanie własne, 2014.

W przypadkach ocen atrakcyjności, wiarygodności i zachęcania do zakupu, gdzie dodatkową zmienną objaśniającą oprócz cech demograficznych było kupowanie żywności pod wpływem reklamy, wykazano istnienie zależności pomiędzy tą właśnie zmienną a wszystkimi trzema wymiarami oceny reklam. W przypadku ocen atrakcyjności i wiarygodności stwierdzono jednak istnienie zależności słabej. Dotyczyło to zwłaszcza atrakcyjności (współczynnik V-Cramera na poziomie 0,159 ), w przypadku wiarygodności zależność była nieco silniejsza (współczynnik V-Cramera na poziomie 0,236). Znacznie większa siła zależności wystąpiła natomiast w przypadku zachęcania do zakupu - w tym przypadku wartość współczynnika V-Cramera osiagnęła poziom 0,484 ).

Jeżeli chodzi natomiast o związek pomiędzy ocenami atrybutów reklamy artykułów żywnościowych a cechami demograficznymi badanych, to zależność istotna statystycznie wystąpiła jedynie w przypadku zależności pomiędzy atrakcyjnością a miejscem zamieszkania, wykształceniem a oceną wiarygodności reklam oraz pomiędzy wiekiem a kupowaniem żywności. W tych trzech przypadkach istotność asymptotyczna testu $\chi^{2}$ osiągnęła wartość niższą niż założone $\alpha=0,05$. Siła tych zależności jest jednak niewielka-współczynniki V-Cramera nie przekraczają poziomu 0,2. 


\section{Podsumowanie}

Przedstawione wyniki badań dotyczących postrzegania reklam artykułów żywnościowych w społeczeństwie polskim pokazują zróżnicowany obraz zjawiska. Rosnąca skala nakładów reklamowych na kategorię żywność i napoje idzie w parze z doskonaleniem sposobów prezentacji treści reklamowych. Stają się one coraz bardziej kreatywne, co przekłada się na wzrost ich atrakcyjności w oczach odbiorców. Wysoko oceniania jest również ich wiarygodność, choć nie zawsze to, co przedstawiane jest w reklamie w sposób atrakcyjny, budzi zaufanie konsumentów. Jednocześnie postrzeganie reklam jako wiarygodnych nie musi wynikać $\mathrm{z}$ ich atrakcyjnego kształtu i treści. Widać to na przykładzie porównania wskaźników atrakcyjności i wiarygodności dla różnych kategorii artykułów żywnościowych. Nie oznacza to też, że reklamy żywności nie budzą wątpliwości - w latach 2007-2015 na reklamy żywności złożonych zostało 241 skarg do Komisji Etyki Reklamy, a za zasadne uznano 125 zarzutów $^{23}$.

Pozytywne oceny atrakcyjności i wiarygodności tylko częściowo implikują skuteczność w kontekście motywowania do zakupu - wskaźnik ten jest o około 1/4 niższy niż dwa poprzednie. Paradoksem jest przy tym, że część osób badanych dokonuje zakupu artykułów żywnościowych pod wpływem reklam, choć negatywnie ocenia je pod względem zachęcania do zakupu. Pojawia się w związku z tym pytanie, skąd biorą się te dysproporcje zaburzające schemat skutecznego oddziaływania reklamy. Otwiera to nową perspektywę badawczą związaną z jakościową identyfikacją związków przyczynowoskutkowych pomiędzy czterema analizowanymi składowymi: atrakcyjnością, wiarygodnością, motywowaniem do zakupu oraz rzeczywistym jego dokonywaniem.

Znamiennym wydaje się też być fakt, że pozytywne oceny różnych aspektów skuteczności reklamy artykułów żywnościowych nie są zasadniczo skorelowane z cechami demograficznymi społeczeństwa. Istotne statystycznie zależności - jeżeli już występują - charakteryzują się słabą siłą. Świadczyć to może o upodabnianiu się nastawienia do reklamy i zbliżonego jej postrzegania w kontekście oddziaływania na procesy decyzyjne.

\section{Bibliografia}

3 proc. więcej na reklamy $w$ Polsce, internet zyskuje kosztem prasy i telewizji, mocno $w$ górę branża handlowa (analiza). http://www.wirtualnemedia.pl/artykul/wydatki-reklamowe-w-polsce2016-internet-zyskuje-kosztem-prasy-i-telewizji-branza-handlowa_[dostęp: 1.07.2017].

Adler R., Rodman G., Understanding Human Communication, Oxford University Press, New York 2000 .

Andreasen A.R.: Attitudes and customer behavior, [w:] L.E. Preston (red.), New Research in Marketing, Institute of Business and Economic Research, University of California, Berkley 1965.

Antonides G., van Raaij W.F.: Zachowania konsumenta. Podręcznik akademicki, PWN, Warszawa 2003.

Belch G.E., Belch M.A.: Advertising and promotion. An integrated marketing comunications perspective, McGraw-Hill, New York 2009.

Bovee C.L., Arens W.F.: Contemporary Advertising, Irwin, Homewood 1983.

Eisend M.: Source Credibility Dimensions in Marketing Communication - A Generalized Solution, „Journal of Empirical Generalisations in Marketing”, 2/2006.

${ }^{23}$ I. Ozimek, J. Szlachciuk, A. Bobola: Reklama żywności w kontekście regulacji prawnych i Kodeksu Etyki Reklamy, „Handel Wewnętrzny”, 4/2017, s. 137-138. 
Engel J.F, Blackwell R.D., Miniard P.W.: Consumer behavior, Dryden Press, Chicago1993.

Engel J.F., Blackwell R.D., Kollat D.T.: Consumer behavior, Holt, Rinehart and Winston, New York 1968

Falkowski A., Tyszka T.: Psychologia zachowań konsumenckich, GWP, Gdańsk 2001.

Hansen F.: Consumer Choice Behavior. A Cognitive Theory, The Free Press, New York 1972.

Howard J.A., Sheth J.N.: The Theory of Buyer Behavior, Wiley, New York 1969.

Jachnis A., Terelak J.F.: Psychologia konsumenta i reklamy, Branta, Bydgoszcz 1998.

Jefkins F.: Advertising, Pitman Publishing, London 1985.

Kozłowska A.: Bohater reklamowy, czyli jak budować wiarygodność w reklamie, „Kwartalnik Kolegium Ekonomiczno-Społecznego Studia i Prace / Szkoła Główna Handlowa”, 1/2013.

Kozłowska A.: Reklama. Techniki perswazyjne, Oficyna Wydawnicza SGH 2011.

Nicosia F.M.: Consumer Decision Processes: Marketing and Advertising Implications, PrenticeHall, Englewood Cliffs 1996.

Nowacki R., Strużycki M.: Reklama w przedsiębiorstwie, Difin, Warszawa 2002.

Nowacki R.: Procesy zarzadzania działalnościa reklamowa $w$ przedsiębiorstwach, [w:] $\mathrm{R}$. Nowacki, M. Strużycki (red.), Reklama w procesach konkurencji, Difin, Warszawa 2011.

Nowacki R.: Reklama, Difin, Warszawa 2005.

Nowacki R.: Ustugi reklamowe w procesie kształtowania pozycji rynkowej przedsiębiorstw - skala i perspektywy wykorzystania, „Handel Wewnętrzny”, 4/2016.

Ozimek I., Szlachciuk J., Bobola A.: Reklama żywności $w$ kontekście regulacji prawnych $i$ Kodeksu Etyki Reklamy, „Handel Wewnętrzny”, 4/2017.

Pohorille M., Mechanizmy $i$ kierunki zmian $w$ konsumpcji społeczeństwa polskiego, UW, Warszawa 1980.

Rudnicki L.: Zachowania konsumentów na rynku, PWE, Warszawa 2012.

Smyczek S., Sowa I.: Konsument na rynku. Zachowania, modele, aplikacje. Difin, Warszawa 2005.

Szczepański J. (red.): Badania nad wzorami konsumpcji, Ossolineum, Wrocław 1977.

\section{Summary}

The aim of the article is to assess perception of advertising of food products in the Polish society and its impact on consumer purchasing decisions. The grounds for the article are findings of the surveys conducted in 2014 among the population aged above 15 years. The findings show that advertisements of food products are quite often assessed as attractive and reliable, while the susceptibility to the impact of advertising of food products is declared by less than half of the population surveyed. There is also great diversification of assessments from the point of view of both respondents' demographic traits and individual product categories.

Key words: advertising, food products, advertising attractiveness, advertising reliability.

Informacje o autorze:

Dr Robert Nowacki

Wyższa Szkoła Finansów i Zarządzania w Warszawie

Wydział Zarządzania i Finansów

Katedra Marketingu

ul. Pawia 55

01-030 Warszawa

email: nowacki@vizja.pl 